\begin{tabular}{|c|c|c}
\hline JURNAL PENELITIAN KESMASY & VOL. 1 NO. 2 & $\begin{array}{c}\text { EDITION: NOVEMBER 2018 - } \\
\text { APRIL 2019 }\end{array}$ \\
\hline & http://ejournal.delihusada.ac.id/index.php/JPKSY & \\
\cline { 2 - 3 } RECEIVED: 17 FEBRUARI 2019 & REVISED: 18 MARET 2019 & ACCEPTED: 20 APRIL 2019 \\
\hline
\end{tabular}

\title{
HUBUNGAN PENGETAHUAN DAN SIKAP IBU RUMAH TANGGA DENGAN PENGGUNAAN GARAM BERYODIUM
}

\author{
Yunita Syahputri Damanik \\ Institut Kesehatan Deli Husada, Jl.Besar No.77 Deli Tua, Deli Serdang \\ Email : yunitadamanik88@gmail.com
}

\begin{abstract}
A long-term sustainable effort is by iodizing salt, which is adding iodine to food ingredients. The aim of this program is that $90 \%$ or more households consume iodized salt according to the requirements, which is 30-80 parts permillion (ppm). The aim of this research was to determine the relationship between knowledge and attitudes of the housewives with the use of iodized salt in Delitua Timur, Deli Serdang. The sampling technique in this research was non probability sampling using a purposive method of 96 people. The analysis carried out using the chi-square test. The results of the research on 96 respondents for the knowledge variable obtained which means there was not relationship between knowledge and the use of iodized salt. And for attitude variables obtained which means there was a relationship between attitudes and use of iodized salt in Delitua Timur, Deli Serdang. The suggested for this research to the society to increase their knowledge and positive attitude to use of iodized salt in an effort to improve health and nutrition.
\end{abstract}

Keyword: Knowledge, Attitude, Iodized Salt, Housewife

\section{PENDAHULUAN}

Pembangunan bangsa Indonesia diarahkan untuk peningkatan kecerdasan dan produktifitas kerja. Upaya yang telah dilakukan dan memiliki dampak positif terhadap peningkatan sumber daya manusia adalah meningkatnya status kesehatan masyarakaat. Di Indonesia GAKY (Gejala Akibat Kekurangan Yodium) merupakan salah satu masalah kesehatan masyarakat yang serius karena dampak yang ditimbulkan berpengaruh terhadap kelangsungan hidup dan kualitas sumber daya manusia.

Kekurangan yodium pada wanita yang sedang hamil beresiko sangat berat yaitu bisa menyebabkan abortus, cacat bawaan pada bayi, lahir mati, gangguan mental, serta gangguan perkembangan saraf.. Gangguangangguan mengakibatkan rendahnya minat belajar anak usia sekolah, rendahnya produktifitas kerja bagi orang dewasa serta timbulnya berbagai permasalahan sosial ekonomi pada masyarakat yang dapat menghambat pembangunan (Depkes RI, 2005).

Begitu seriusnya dampak GAKY yang ditimbulkan, pemerintah Indonesia melakukan upaya penanggulangan GAKY yaitu dengan: (1) distribusi kapsul minyak beryodium kepada seluruh wanita usia subur (15-49 tahun) di daerah endemik berat dan endemik sedang sebagai upaya jangka pendek. (Depkes RI, 2004).

Hasil Riskesdas 2013 menunjukkan bahwa kecenderungan rumah tangga mengkonsumsi garam yang beryodium cukup berdasarkan tempat tinggal di perkotaan dengan persentase sebesar $70,4 \%$ dan yang berada di pedesaan mempunyai persentase sebesar $56,3 \%$. Di wilayah Sumatera Utara, kecenderungan rumah tangga mengkonsumsi garam yang beryodium cukup sekitar $87,6 \%$ sedangkan rumah tangga mengkonsumsi garam yang beryodium kurang sekitar $11,1 \%$ dan rumah tangga mengkonsumsi garam yang tidak beryodium 


\begin{tabular}{|c|c|c|}
\hline JURNAL PENELITIAN KESMASY & VOL. 1 NO. 2 & $\begin{array}{c}\text { EDITION: NOVEMBER } 2018- \\
\text { APRIL } 2019\end{array}$ \\
\hline & http://ejournal.delihusada.ac.id/index.php/JPKSY & \\
\hline RECEIVED: 17 FEBRUARI 2019 & REVISED: 18 MARET 2019 & ACCEPTED: 20 APRIL 2019 \\
\hline
\end{tabular}

sekitar $1,2 \%$. Uraian tersebut diatas menjadi alasan penulis untuk melakukan penelitian mengenai hubungan antara pengetahuan dan sikap ibu rumah tangga dengan penggunaan garam beryodium.

\section{METODE PENELITIAN}

Penelitian ini menggunakan metode survey analitik dengan pendekatan cross sectional. Survey cross sectional yaitu suatu penelitian yang mempelajari dinamika korelasi antara faktor-faktor resiko dengan efek melalui pendekatan observasi atau pengumpulan data sekaligus pada suatu waktu. Artinya setiap subjek penelitian hanya diobservasi sekali saja dan diamati pada waktu yang sama (Notoatmodjo, 2005).

Penelitian ini dilakukan di Kelurahan Delitua Timur Kabupaten Deli Serdang, Sumatera Utara. Populasi pada penelitian ini adalah seluruh ibu rumah tangga yang berada di Kelurahan Delitua Timur Kab. Deli Serdang. Jenis pengambilan sampel dalam penelitian ini adalah non probability sampling menggunakan metode purposive. Peneliti menggunakan rumus sampel minimum. Besar sampel dengan nilai proporsi yang ditetapkan $(0,5), \mathrm{Z} 1-\mathrm{a} / 2=$ 1,96 pada $a=95 \%$. Maka jumlah sampel keseluruhan yang diambil untuk penelitian adalah 96 responden. Instrumen yang digunakan dalam penelitian ini adalah dalam bentuk kuesioner berupa daftar pertanyaan yang telah disusun dengan baik. Iodina test, adalah test yang digunakan untuk menguji garam beryodium rumah tangga.

Analisis Univariat hanya menampilkan distribusi frekuensi dari masing-masing variable yang diteliti. Sebelum dilakukan analisis bivariat, dilakukan uji normalitas data terlebih dahulu. Hal ini dilakukan untuk mengetahui datanya berdistribusi normal atau tidak. Menurut dahlan (2011), syarat uji normalitas ada dua yaitu metode deskriptif dan metode analitis. Dalam menggunakan metode analitik parameter yang digunakan yaitu kolmogorov smirnov (sampel > 50) dan Shapiro Wilk (sampel < 50). Data dikatakan berdistribusi normal jika sig > 0,5. Jika ternyata data tidak berdistribusi normal, maka analisis yang dilakukan menggunakan uji chi-square.

\section{HASIL DAN PEMBAHASAN}

Hasil penelitian ini dinyatakan dalam tabel berikut.

Tabel 1. Responden berdasarkan umur, pekerjaan, dan pendidikan

\begin{tabular}{ccc}
\hline $\begin{array}{c}\text { Umur } \\
\text { (Tahun) }\end{array}$ & F & \% \\
\hline $18-28$ & 49 & 51,0 \\
$29-38$ & 30 & 31,3 \\
$>39$ & 17 & 17,7 \\
\hline Total & $\mathbf{9 6}$ & $\mathbf{1 0 0 , 0}$ \\
\hline
\end{tabular}

Tabel 2. Responden berdasarkan Pekerjaan

\begin{tabular}{ccc}
\hline Pekerjaan & F & \% \\
\hline Pegawai & 10 & 10,4 \\
Wiraswasta & 27 & 28,1 \\
Ibu Rumah & 59 & 61,5 \\
\hline Tangga & $\mathbf{9 6}$ & $\mathbf{1 0 0 , 0}$ \\
\hline Total &
\end{tabular}

Tabel 3. Responden berdasarkan Pendidikan

\begin{tabular}{ccc}
\hline Pendidikan & F & \% \\
\hline SMP & 29 & 30,2 \\
SMA & 34 & 35,4 \\
Perguruan Tinggi & 33 & 34,4 \\
\hline Total & $\mathbf{9 6}$ & $\mathbf{1 0 0 , 0}$ \\
\hline
\end{tabular}

Tabel 4. Responden berdasarkan Pengetahuan

\begin{tabular}{ccc}
\hline Pengetahuan & F & $\%$ \\
\hline Baik & 88 & 91,7 \\
Kurang & 8 & 8,3 \\
\hline Total & $\mathbf{9 6}$ & $\mathbf{1 0 0 , 0}$ \\
\hline
\end{tabular}

Tabel 5. Responden berdasarkan Sikap

\begin{tabular}{ccc}
\hline Sikap & F & \% \\
\hline Positif & 84 & 87,5 \\
Negatif & 12 & 12,5 \\
\hline Total & $\mathbf{9 6}$ & $\mathbf{1 0 0 , 0}$
\end{tabular}




\begin{tabular}{|c|c|c|}
\hline JURNAL PENELITIAN KESMASY & VOL. 1 NO. 2 & $\begin{array}{c}\text { EDITION: NOVEMBER } 2018- \\
\text { APRIL } 2019\end{array}$ \\
\hline & http://ejournal.delihusada.ac.id/index.php/JPKSY & \\
\hline RECEIVED: 17 FEBRUARI 2019 & REVISED: 18 MARET 2019 & ACCEPTED: 20 APRIL 2019 \\
\hline
\end{tabular}

Tabel 6. Responden berdasarkan Penggunaan

Garam

\begin{tabular}{ccc}
\hline $\begin{array}{c}\text { Penggunaan } \\
\text { Garam Beryodium }\end{array}$ & F & \% \\
\hline Beryodium & 83 & 86,5 \\
Tidak Beryodium & 13 & 13,5 \\
\hline Total & $\mathbf{9 6}$ & $\mathbf{1 0 0 , 0}$ \\
\hline
\end{tabular}

Tabel 7. Hubungan Pengetahuan Ibu dengan Penggunaan Garam Beryodium

\begin{tabular}{cccccc}
\hline \multirow{2}{*}{$\begin{array}{c}\text { Pengetahuan } \\
\text { Ibu }\end{array}$} & Beryodium & $\mathbf{\%}$ & $\begin{array}{c}\text { Tidak } \\
\text { Beryodium }\end{array}$ & \% & \multirow{2}{*}{ P-Value } \\
\cline { 2 - 5 } Baik & 76 & 86,4 & 12 & 13,6 & \\
Kurang & 7 & 87,5 & 1 & 12,5 & \multirow{2}{*}{1,000} \\
\cline { 2 - 5 } Total & $\mathbf{8 3}$ & & $\mathbf{1 3}$ & \\
\hline
\end{tabular}

Tabel 8. Hubungan Sikap Ibu dengan Penggunaan Garam Beryodium

\begin{tabular}{|c|c|c|c|c|c|c|c|c|}
\hline \multirow[b]{2}{*}{ Sikap Ibu } & \multicolumn{4}{|c|}{ Konsumsi Garam } & \multicolumn{2}{|c|}{$95 \% \mathrm{CI}$} & \multirow[b]{2}{*}{ P-Value } & \multirow{2}{*}{$\begin{array}{c}\text { Odd } \\
\text { Ratio }\end{array}$} \\
\hline & Beryodium & $\%$ & $\begin{array}{c}\text { Tidak } \\
\text { Beryodium }\end{array}$ & $\%$ & Lower & Upper & & \\
\hline Positif & 76 & 90,5 & 8 & 9,5 & & & & \\
\hline Negatif & 7 & 58,3 & 5 & 41,7 & 1,743 & 26,421 & 0,010 & 6,786 \\
\hline Total & 83 & & 13 & & & & & \\
\hline
\end{tabular}

\section{Pembahasan}

Tingkat pengetahuan responden pada penelitian ini dilihat berdasarkan skor yang diperoleh dari sejumlah jawaban atas pertanyaan pada kuesiner mengenai garam beryodium. Hasil penelitian ini menunjukkan 88 orang responden memiliki pengetahuan yang baik mengenai penggunaan garam beryodium, namun dari 88 orang tersebut, ada 12 orang $(13,6 \%)$ yang mengkonsumsi garam tidak beryodium.

Berdasarkan wawancara singkat yang dilakukan saat memberikan kuesioner kepada responden, didapat beberapa alasan mereka tidak menggunakan garam beryodium, diantaranya harga garam beryodium lebih mahal jika dibandingkan dengan garam tidak beryodium, dan untuk beberapa keperluan, mereka cenderung lebih memilih menggunakan garam kasar yang mengandung yodium rendah atau bahkan tidak mengandung yodium sama sekali seperti pada masakan sambal.

Dari uji statistik chi-square diperoleh hasil $\mathrm{p}$ $>0,05$ sehingga tidak ada hubungan yang bermakna antara pengetahuan dengan penggunaan garam beryodium. Sesuai dengan teori Notoatmodjo (1997) yang menyatakan bahwa peningkatan pengetahuan tidak selalu menyebabkan perubahan perilaku. Sehingga meskipun tingkat pengetahuan responden terbilang sangat baik, namun tidak mempengaruhi penggunaan garam beryodium karena kebiasaan yang kurang baik dalam penggunaan garam beryodium. Penelitian ini sejalan dengan hasil penelitian Atika Kurniasih (2012) menyatakan bahwa tidak ada hubungan yang signifikan antara pengetahuan dengan penggunaan garam 


\begin{tabular}{|c|c|c}
\hline JURNAL PENELITIAN KESMASY & VOL. 1 NO. 2 & $\begin{array}{c}\text { EDITION: NOVEMBER 2018 - } \\
\text { APRIL 2019 }\end{array}$ \\
\hline & http://ejournal.delihusada.ac.id/index.php/JPKSY & \\
\cline { 2 - 3 } RECEIVED: 17 FEBRUARI 2019 & REVISED: 18 MARET 2019 & ACCEPTED: 20 APRIL 2019 \\
\hline
\end{tabular}

beryodium berdasarkan hasil uji statistik yang dilakukan didapat $p$-value sebesar 0,996.

Hasil penelitian yang sama juga ditemukan oleh Andi Hikmawati di Kecamatan Parangloe Kab. Gowa tahun 2012, dimana dari 69 responden didapatkan $p$-value 0,536 yang bermakna bahwa tidak ada hubungan yang signifikan antara pengetahuan dengan penggunaan garam beryodium.

Pada penelitian ini, sikap responden didapatkan dari skor yang diperoleh responden dari sejumlah pernyataan sikap pada kuesioner (setuju, ragu-ragu, dan tidak setuju) mengenai garam beryodium. Hasil penelitian menunjukkan dari 84 orang responden yang memiliki sikap positif, ada 76 orang $(90,5 \%)$ menggunakan garam beryodium dan 8 orang $(9,5 \%)$ tidak menggunakan garam beryodium. Serta dari 12 orang responden yang memiliki sikap negatif terhadap garam beryodium terdapat 7 orang yang menggunakan garam beryodium dan sisanya 5 orang $(41,7 \%)$ tidak menggunakan garam beryodium. $\mathrm{B}$

Berdasarkan uji statistik chi-square diperoleh nilai $p$ sebesar 0,010 . Karena nilai $p$ lebih kecil dari 0,05 maka $\mathrm{H}_{0}$ ditolak yang berarti ada hubungan yang signifikan antara sikap ibu dengan penggunaan garam beryodium di rumah tangga. Dan didapat nilai Odd Ratio pada tabel Risk 6,786 yang berarti ibu rumah tangga yang memiliki sikap negatif terhadap garam beryodium memiliki potensi 7 kali lipat untuk tidak menggunakan garam beryodium dibandingkan dengan ibu rumah tangga yang memiliki sikap positif terhadap garam beryodium.

Hasil penelitian ini juga sejalan dengan penelitian Andi Hikmawati di Kecamatan Parangloe Kab. Gowa tahun 2012, dimana dari 69 responden didapatkan nilai $p$ sebesar 0,015 yang berarti ada hubungan yang signifikan antara sikap ibu rumah tangga dengan penggunaan garam beryodium.

\section{KESIMPULAN}

Pengetahuan ibu tidak memiliki hubungan yang signifikan dengan penggunaan garam beryodium dirumah tangga karena pengetahuan yang baik belum tentu disertai perilaku yang baik pula. Ada hubungan yang signifikan antara sikap ibu dengan penggunaan garam beryodium di rumah tangga dimana ibu rumah tangga yang memiliki sikap negatif terhadap garam beryodium memiliki peluang 7 kali lipat lebih besar untuk tidak menggunakan garam beryodium dibandingkan dengan ibu rumah tangga yang memiliki sikap positif tentang garam beryodium.

\section{DAFTAR PUSTAKA}

Arisman, 2004, Gizi dalam Daur Kehidupan, Jakarta: EGC.

BPS, 1995, Garam Beryodium di Rumah Tangga, Jakarta: BPS.

Depkes RI, 2003, Pedoman Umum Gizi Seimbang (Panduan untuk Petugas), Jakarta: Bakti Husada.

Leily Amalia, dkk, 2015, Pengetahuan, Sikap, dan Praktek Gizi Ibu terkait Iodium dan Pemilihan Jenis Garam Rumah Tangga di Wilayah Pegunungan Cianjur, Jurnal Gizi Pangan, 10(2), 134.

Merryana Adriani, 2012, Pengantar Gizi Masyarakat, Jakarta: PT. Fajar Interpratama Mandiri.

Soekidjo Notoatmodjo, 2003, IImu Kesehatan Masyarakat, Jakarta: PT. Rineka Cipta.

Subhan, 2014, Analisis Kandungan Iodium dalam Garam Butiran Konsumsi yang Beredar di Pasaran Kota Ambon, Jurnal Fikratuna, 6, 292.

Toto Sudargo, dkk, 2018, Defisiensi Yodium, Zat Besi, dan Kecerdasan, Yogyakarta: UGM Press 